\title{
Sustainability of Maize-Based Production Practices among Small-scale Maize Farmers in Anambra State, Nigeria
}

Offiah EO, Nwoye II", and Nwankwo EC Department of Agricultural Economics \& Extension, Chukwuemeka Odumegwu Ojukwu University, Igbariam Campus, Nigeria

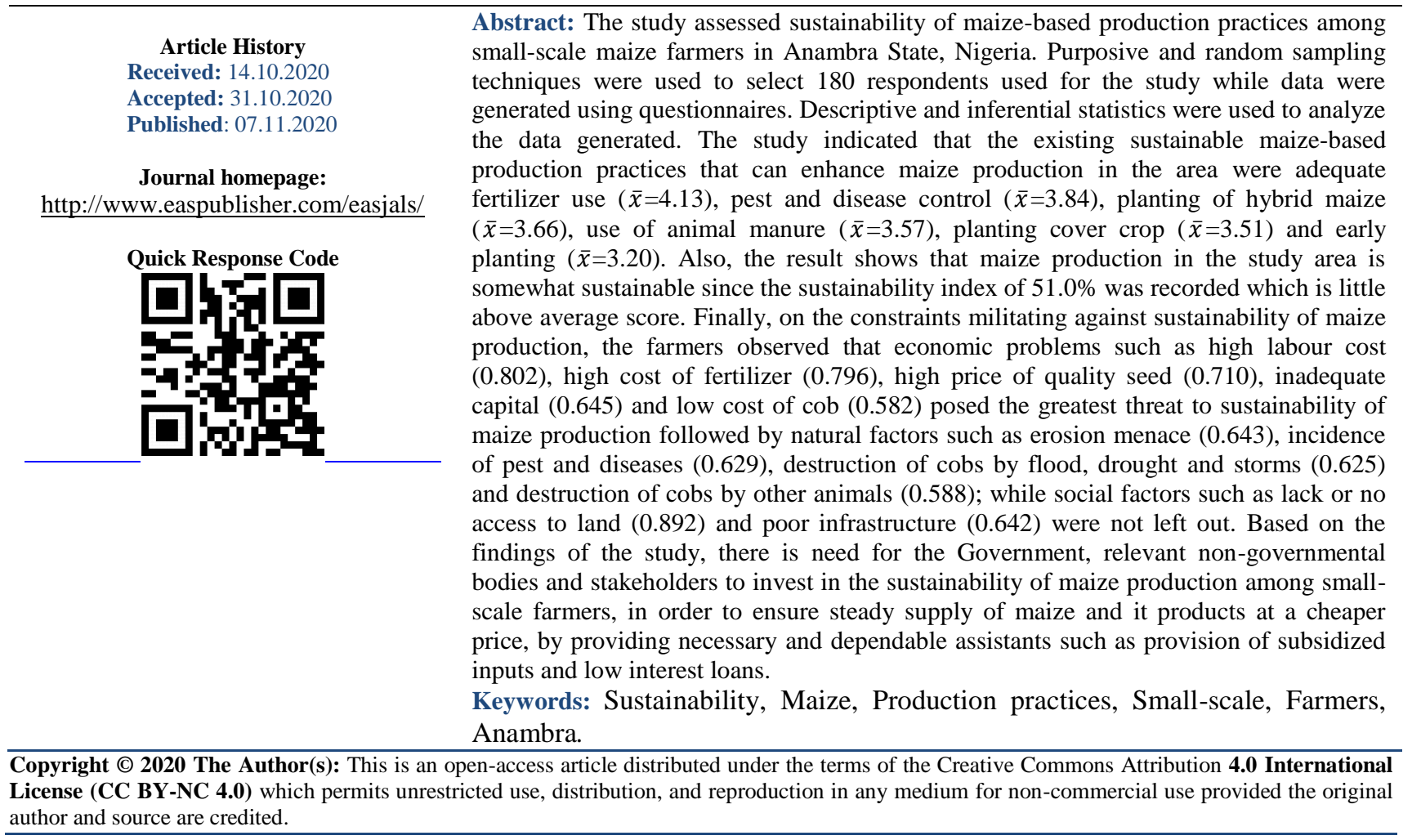

\section{INTRODUCTION}

In the last decade, sustainability of best agronomic practices in agriculture has generated a lot of interest within the scientific community. Most especially, the interest is geared towards poverty alleviation and food security in the developing countries where population growth rate is high with natural and environmental resources depletion on the increase. As a result, agricultural sustainability through proper use of soil and water resources have become a global issue of modern times as every country now battle to feed her ever increasing population by closing the gap between demand and supply of agricultural produce. Sustainability of food production is one of the paramount issues facing both developed and developing countries of the world. It hinges on providing food with the available and accessible resources for both present and future generations.
According to Onyango [1], increasing human population against declining staple food crop yield trend, food insecurity is inevitable. As such, it is pertinent to note that the use of traditional farming systems in less fertile lands; the poor productivity of such system and the emergence of unsustainable farming will pose the greatest threat to food security in Nigeria [2]. More so, it is worthy to emphasis that smallholder maize production is often characterized by low yields, which are often significantly lower than the potential for the land. However, sustainability of maize production is not only a question of yields, but also of protection of the environmental resources, social welfare, and the livelihoods of the farmers in rural and urban communities [3]. Sustainability of maize production entails production of maize with the available and accessible resources for the present generation without compromising the future generation as well. It is the use of best agronomic production 
practices such as appropriate application of fertilizer, planting of hybrid crops, pest and disease resistant crops, pest and disease management, use of animal manure, early planting and planting of cover crops.

According to Onuk, Ogara, Yahaya and Nannim [4], maize is one of the most abundant food crops in Nigeria; about $80 \%$ is consumed by man and animals while about $20 \%$ is utilized in the production of industrial processed food and food related products such starch, oil, high fructose, corn sweetener and cereal. On the other hand, Gupta [5] noted that maize has immense potential to close up the gap of food requirement among teeming human population in various developing countries since it has a great significance as human food, animal feed and diversified uses in a large number of industrial products. Also, Abu, Raoul and Okpachu [6] were of the view that maize is regarded by the majority of people as a crop solely for home consumption rather than for cash during the past three decades. Thus, the need for its sustainability arose as a result of the variety of its uses. On this background, Kukta [7] indicated that improved maize cultivars are a key element among practices used for integrated pest management and other approaches for agricultural sustainability.

Now, in addressing the challenges facing maize production and its sustainability, Ayeni [8] noted that continuous use of acid forming fertilizers such as sulphate of ammonia, urea and ammonium nitrate contributes significantly to soil acidity; and as such, hindering agricultural and environmental sustainability. In addition, Onuk, et al. [9] noted that despite the economic importance of maize to the teeming populace in Nigeria, it has not been produced to meet food and industrial need of the country. This could perhaps be attributed to low productivity from maize farms. More so, many studies have been carried out on maize but all hinged on economic viability without a wholesome look at its sustainability. Example is the study conducted by Nkamigbo, Nwoye, Makwudo and Gbughemobi [10], Oladejo and Adetunji [11], Oyewo and Fabiyi, [12] and Fawole and Oladele [13]. As such, this study seeks to look at the sustainable production practices that could enhance maize production other than the excessive use of fertilizer seen among maize farmers in increasing maize production. The study specifically

i. identified the existing maize-based production practices among the maize farmers;

ii. evaluated sustainability of maize production in the area; and

iii. identified constraints to sustainability of maize production in the area

\section{METHODOLOGY}

The study area was Anambra State of Nigeria. Boundaries around the state are formed by Delta State to the west, Imo State to the south, Enugu state to east and Kogi State to north. The population for the study was delimited to all small-scale maize farmers in the state. Purposive and random sampling techniques were employed in the selection of 180 maize farmers used for the study. In stage I, three Agricultural Zones (Aguata, Anambra and Awka) were selected purposively out of the four Agricultural Zones (Aguata, Anambra, Awka and Onitsha) in existence. The purposive selection was based on the fact that majority of the small-scale maize farmers concentrate in the selected study areas. Stage II involved selection of two Local Government Areas from each of the three selected AZs making a total of six (6) LGAs. Stage III involved random selection of three farming communities from each of the six (6) LGAs, making a total of 18 farming communities. Finally, in stage IV, ten (10) maize farmers were selected from the 18 farming communities randomly to make a total of the needed 180 respondents. Data for the study were obtained from both primary and secondary sources and data generated were analyzed using both descriptive (frequency, means and percentage) and inferential statistics (factor analysis and sustainability index). All the analysis was conducted using IBM SPSS Statistics, version 23.0.

Objective i was achieved using 5-point Likert type scale. The 5-point rating availed the farmers the opportunity to choose the best practice they think that could enhance maize sustainability in the study area. The rating were in the order: Strongly agreed $(\mathrm{SA})=5$, agreed $(A)=4$, neutral $(N)=3$, disagree $(D)=2$ and strongly disagree $(\mathrm{SD})=1$. The mean score of the respondents based on the five-point scale was $5+4+3+2+1=15,15 \div 5=3.00$. Using the interval scale of 0.05 , the upper limit cut-off point will be $3.00+0.05$ $=3.05$. The lower limit was $3.00-0.05=2.95$. Based on these, mean scores below 2.55 (i.e. MS< 2.95) were regarded as not important. The mean scores between 3.05 considered important and mean score greater than 3.05 (i.e. MS >3.05) were however considered as very important practices.

Sustainability of maize production was estimated using sustainability index, the factors that could lead to improved maize production (crop yield, crop rotation, use of organic manure, local employment etc) were subtracted from the factors that could lead to un-sustainability of maize production (amount of pesticides used, herbicides, fungicides, nitrate fertilizer and phosphate fertilizer). The operational index was used to achieve objective ii and the model was stated as follows:

$\mathrm{S}=\sum \mathrm{X}_{\mathrm{i}}-\sum \mathrm{Y}_{\mathrm{j}}$

$\mathrm{S}=$ Trend of sustainability

$\mathrm{X}_{1}=$ crop yield

$\mathrm{X}_{2}=$ Execution of crop rotation

$\mathrm{X}_{3}=$ Usage of organic and/or green manures

$\mathrm{X}_{4}=$ Creation of local employment

$\mathrm{X}_{5}=$ Access to resources and support services

$\mathrm{X}_{6}=$ Provision of public local goods

$\mathrm{X}_{7}=$ Trend of change in water resources (at the farm) 
$\mathrm{X}_{8}=$ Trend of change in soil resources (at the farm)

$\mathrm{Y}_{1}=$ Amount of pesticides consumption in the farm in one cultivation season

$\mathrm{Y}_{2}=$ Amount of herbicides consumption in the farm in one cultivation season

$\mathrm{Y}_{3}=$ Amount fungicides consumption in the farm in one cultivation season

$\mathrm{Y}_{4}=$ amount of nitrate fertilizer consumption per production

$\mathrm{Y}_{5}=$ Amount of phosphate fertilizer consumption per production

Exploratory factor analysis model was used to achieve the constraints to improved maize production.

$\mathrm{Y}_{1}=\mathrm{a}_{11} \mathrm{x}_{1}+\mathrm{a}_{12} \mathrm{x}_{2}+* * *+\mathrm{a}_{1 \mathrm{n}} \mathrm{x}_{\mathrm{n}}$

$\mathrm{Y}_{2}=\mathrm{a}_{21} \mathrm{x}_{1}+\mathrm{a}_{22} \mathrm{X}_{2}+* * *+\mathrm{a}_{2 \mathrm{n}} \mathrm{X}_{\mathrm{n}}$

$\mathrm{Y}_{3}=\mathrm{a}_{31} \mathrm{x}_{1}+\mathrm{a}_{32} \mathrm{X}_{2}+* * *+\mathrm{a}_{3 \mathrm{n}} \mathrm{x}_{\mathrm{n}}$

$\mathrm{Y}_{\mathrm{n}}=\mathrm{a}_{\mathrm{n} 1} \mathrm{X}_{\mathrm{n}}+\mathrm{a}_{\mathrm{n} 2} \mathrm{X}_{2}+* * *+\mathrm{a}_{\mathrm{nn}} \mathrm{X}_{\mathrm{n}}$

Where:

$\mathrm{Y}_{1}, \mathrm{Y}_{2}, \mathrm{Y}_{3}, \ldots, \mathrm{Y}_{\mathrm{n}}=$ Observed constraints facing maize production

$\mathrm{a}_{1}-\mathrm{a}_{\mathrm{n}}=$ Factor of correlation coefficient

$\mathrm{x}_{1}-\mathrm{x}_{\mathrm{n}}=$ unobserved underlying factor constraints

For this study, factors of 0.30 and above were highlighted in bold letters and used for the analysis and otherwise ignored.

\section{RESULTS AND DISCUSSION}

\section{Existing Production Practices that could Enhance} Maize Production in the study Area

Table 1 shows the responses and corresponding mean scores of the maize farmers on the existing maize-based production practices that could lead to sustainability of maize production in the study area. From the result, adequate use of organic fertilizer $(\bar{x}=4.13)$, pest and disease control $(\bar{x}=3.84)$, planting hybrid maize $(\bar{x}=3.66)$, use of animal manure $(\bar{x}=3.57)$, planting cover crop $(\bar{x}=3.51)$ and early planting $(\bar{x}=3.20)$ were the accepted maize-based production practices that can bring about sustainable maize production in the area while other practices such as erosion control and liming were not left behind. Whereas, crop rotation ( $\bar{x}=2.83$ ), mixed farming $(\bar{x}=2.16)$, use of irrigation $(\bar{x}=1.32)$ and good storage system $(\bar{x}=1.65)$ were not indicated by the maize farmers as practices that can bring about sustainability of maize production in the area.

For emphasis, the result shows that the maize farmers identified and accepted practices such as proper and adequate use of organic fertilizer, adequate pest and diseases control, and cultivation of hybrid maize as the prerequisites for sustainable maize production. However, crop rotation and mixed cropping that were not indicated by the farmers; may be as a result of the fact that most of the farmers do not own a land and as such cultivate on rented plots and as such, limits them from practicing such elaborate agronomic practices. Whereas, the use of irrigation system which; was equally not indicated by the maize farmers can be attributed to wet season farming. In other words, the maize farmers only engage in wet season production and as such; they wait till the onset of rain to start cultivation. On the other hand, the storage system as rejected by the farmers can be attributed to limited yield which barely meet up with the level of food demand and as such, the maize farmers do not see the need for storage. Hence, the farmers sell off their produce since they do not see the need for storage while the wholesalers and partly retailers import from nearby states as the once produced within the state are not enough.

Table-1: Mean scores on existing practices that could lead to sustainability of maize production

\begin{tabular}{|l|l|l|}
\hline Existing practices & Mean scores & Decision \\
\hline Adequate use of organic fertilizer & 4.13 & Accept \\
\hline Pest and disease control & 3.84 & Accept \\
\hline Planting hybrid maize & 3.66 & Accept \\
\hline Use of animal manure & 3.57 & Accept \\
\hline Planting cover crop & 3.51 & Accept \\
\hline Early planting & 3.20 & Accept \\
\hline Practice crop rotation & 2.83 & Reject \\
\hline Engage in mixed farming & 2.16 & Reject \\
\hline Use of irrigation & 1.32 & Reject \\
\hline Good storage system & 1.65 & Reject \\
\hline Others & 2.95 & Accept \\
\hline
\end{tabular}

Source: field survey 2014 (Decision rule: $<2.95=$ reject and $\geq 2.95$ accept)

\section{Evaluation of Maize Production Sustainability among Maize Farmers in Anambra State}

Table 2 shows mean score and percentage contribution of the sustainability variables as obtained from the respondents in the proportion of 1 to 10 . From the table, the practices that could lead to sustainability loaded more than half $(54.6 \%)$ while that of the un- sustainability variables loaded $45 \%$. The study went further to calculate the percentage sustainability of maize production using the sustainability index (summation of factors that could lead to sustainability less summation of factors that are unsustainable) as indicated in the methodology of this study. The result of sustainability index is given below: 
$\mathrm{S}=$ sustainable practices - unsustainable practices

$\mathrm{S}=30.5-25.4$

$\mathrm{S}=5.1$

Therefore: $=\frac{5.1}{10} \times \frac{100}{1}$

$\mathrm{S}=51 \%$

From the result of Sustainable Index (51.0\%) obtained, maize production in the area is somewhat sustainable and slightly above average. The result could be attributed to farmers' inability to strictly adhere to best agronomic practices that could bring about sustainable maize production in the area. Doubtfully, it is difficult to do well in sustainable agriculture without farmers consistent and persistence application of best agronomic practices. Therefore, since our survival as humans is largely dependent on food, hence, progress toward sustainable food production is ultimately our only hope for survival.

Table-2: Average scores and percentage contribution of the factors that could lead to sustainability of maize production

\begin{tabular}{|l|l|l|}
\hline Variables & Average Score & $\begin{array}{l}\text { Percentage } \\
\text { Contribution }\end{array}$ \\
\hline A: sustainable variables & & \\
\hline Crop yield & 4.5 & 8.05 \\
\hline Execution of Crop rotation & 3.6 & 6.37 \\
\hline Usage of organic manure & 3.9 & 7.01 \\
\hline Provision of local employment & 4.9 & 8.73 \\
\hline Usage of crop stubble & 3.7 & 6.66 \\
\hline Conservation practice & 3.4 & 6.08 \\
\hline Trend of change in water resources (at farm) & 3.4 & 6.14 \\
\hline Trend of change in soil resources (at farm) & 3.1 & 5.56 \\
\hline Sub-total & $\mathbf{3 0 . 5}$ & $\mathbf{5 4 . 6 0}$ \\
\hline B: unsustainable variables & & \\
\hline Amount of pesticide consumed in the farm per cultivation & 6.3 & 11.28 \\
\hline Amount of herbicides consumed in the farm per cultivation & 3.9 & 6.90 \\
\hline Amount of fungicides used in the farm per season & 3.6 & 6.49 \\
\hline Amount of nitrate fertilizer consumption per production & 5.4 & 9.64 \\
\hline Amount of phosphate fertilizer consumption per production & 6.2 & 11.09 \\
\hline Sub-total & $\mathbf{2 5 . 4}$ & $\mathbf{4 5 . 4 0}$ \\
\hline Total & $\mathbf{5 5 . 9}$ & $\mathbf{1 0 0 . 0 0}$ \\
\hline
\end{tabular}

Source: field survey 2014.

\section{Constraints Mitigating Sustainability of Maize Production in the Study Area}

Table 3 shows the result obtained from the factor analysis. After the rotation the Kaiser-MeyerOlkin (KMO) obtained was $0.869 \%$ which confirms that factor analysis is appropriate for the sample, and the Barteltt's test of SphericityX $X^{2}$ (78) was 714.554 $\mathrm{p}<.01$ which is above the limit of 0.5 . Three factors, namely economic, natural and social factors were extracted. After rotation, the first factor accounted for $21.06 \%$ of the variance, the second factor accounted for $19.67 \%$ while the third accounted for $15.22 \%$ of the variance and cumulatively, the first three factors loaded $55.94 \%$ showing that more than half of the variance is accounted for by the first three factor (high labor, fertilizer and quality seed cost) which fall under economic factors. The result indicated that the first factor named economic factor was the major problem facing the maize farmers and these factors includes Vo.1- high labor cost (0.802), Vo.2- high cost of fertilizer (0.796), Vo.3 - high price of quality seed (0.710), Vo.4- inadequate capital (0.645) and Vo.5- low cost of cob (0.582). This finding is in agreement with the observation made by Okeke (2014), that the major problem faced by fresh maize farmers in Anambra State is lack of capital.

The second most important was natural factors which included Vo.6- erosion menace (0.643), Vo.7incidence of pest and diseases (0.629), Vo.8destruction of cobs by flood, drought and storms (0.625) and Vo.9- destruction of cobs by other animals (0.588). These variables fall under factors that are caused by nature which the farmers have little or no solution to them. The result of the study aligns with the findings of Olalinde, Manyoung and Akintola [14] who observed that majority of the farmers had their crops affected by drought, flood, wind, storm, diseases and pests. Finally, the last factors which were identified by the maize farmers and categorized as social factors were Vo.10- lack or no access to land (0.892) and Vo.11poor infrastructure (0.642). These were grouped as social factor as a result of culture, since women and some group do not have access to land and infrastructure. From the study, it was observed that economic problems were the greatest threat to maize sustainability followed by natural or environmental factors and finally the social factors as identified by the farmers. 
Table-3: Varimax Rotated component matrix on the constraints faced by the farmers

\begin{tabular}{|l|l|l|l|l|}
\hline $\begin{array}{l}\text { Variable } \\
\text { Code }\end{array}$ & Variable Names & $\begin{array}{l}\text { Factor 1 } \\
\text { (economic factors) }\end{array}$ & $\begin{array}{l}\text { Factor 2 } \\
\text { (natural } \\
\text { factors) }\end{array}$ & $\begin{array}{l}\text { Factor 3 (social } \\
\text { factors) }\end{array}$ \\
\hline Vo.1 & High cost of and unavailability of labor & $\mathbf{0 . 8 0 2}$ & 0.114 & 0.168 \\
\hline Vo. 2 & High cost of fertilizer & $\mathbf{0 . 7 9 6}$ & -0.007 & 0.293 \\
\hline Vo.3 & Price of quality seed & $\mathbf{0 . 7 1 0}$ & 0.170 & 0.177 \\
\hline Vo.4 & Inadequate capital & $\mathbf{0 . 6 4 5}$ & 0.207 & -0.233 \\
\hline Vo.5 & Low cost of cobs & $\mathbf{0 . 5 8 2}$ & 0.210 & 0.082 \\
\hline Vo.6 & Erosion menace & 0.245 & $\mathbf{0 . 6 4 3}$ & 0.156 \\
\hline Vo.7 & Incidence of pest and disease & 0.160 & $\mathbf{0 . 6 2 9}$ & 0.202 \\
\hline Vo. 8 & Destruction of crop by flood and storm & -0.017 & $\mathbf{0 . 6 2 5}$ & -0.089 \\
\hline Vo. 9 & Destruction of cob by other animals & 0.003 & $\mathbf{0 . 5 8 8}$ & 0.075 \\
\hline Vo.10 & Access to suitable of land & -0.020 & -0.207 & $\mathbf{0 . 8 9 2}$ \\
\hline Vo.11 & Poor infrastructural development & 0.092 & 0.230 & $\mathbf{0 . 6 4 1}$ \\
\hline Vo.12 & Lack of agricultural extension agents & 0.065 & -0.082 & 0.221 \\
\hline Vo.13 & Inadequate market for product & -0.100 & 0.126 & -0.215 \\
\hline
\end{tabular}

Note: Extraction method: principal component analysis, rotation method: oblimin with Kaiser Normalization, rotation converged in 25 iterations. Factor loading over 0.30 appear in bold.

\section{CONCLUSION AND RECOMMENDATIONS}

The fundamental issue in sustainability of maize production is to enlighten maize farmers on how to manage or combine available resources, inputs and practices to maximize crop yield while being mindful of the surrounding environment. From the study, there was increasing trend in maize production and the positive growth is associated with hybrid maize, use of recommended quantity and use of organic fertilizer. However, high labour cost, high cost of fertilizer, high price of quality seed, inadequate capital, low cost of cob, erosion menace, incidence of pest and diseases, destruction of cobs by flood, drought and storms and destruction of cobs by other animals were identified as factors militating against sustainability of maize production in the area. Based on the findings, there is need for the Government, relevant non-governmental organizations and stakeholders to pay attention to sustainability of maize production in the study area, in order to ensure steady and adequate supply of maize at cheaper price. This can be achieved through the provision of necessary assistance such extension services, subsidized inputs and low interest loans. Farmers on the other hand, should be encouraged to practice best agronomic practices that will bring about sustainability of maize production. This can be achieved through the help of the extension agents designated to their locality.

\section{REFERENCES}

1. Onyango, O.C. (2010). Fertilizer options for sustainable maize production in the Trans-nzoia district of Kenya. African Journal of Agricultural Research, 5(11), 1203-1212.
2. Amujoyegbe, B.J., \& Bamidele. (2012). Farming system analysis of two agro-ecological zones of Southwestern Nigeria. Agricultural Science Research Journal, 2(1), 13 - 19.

3. Walker, N.J, \& Schulze, R.E. (2008). An assessment of sustainable maize production under different management and climate scenarios for smallholder agro-ecosystems in Kwazulu-Natal, South Africa. School of Bio-resources Engineering and Environmental Hydrology, University of KwaZulu-Natal

4. Onuk, E.G., Ogara, I.M., Yahaya, H., \& Nannim, N. (2010). Economic analysis of maize production in Mangu Local Government Area of Plateau State, Nigeria. Journal of production, agriculture and technology, 6(1), 1-11.

5. Gupta, S. (2011). Sustainability of scientific maize cultivation practices in Utter Pradesh, India. Journal of Biology, Agriculture and Healthcare, 1(4), 14-18.

6. Abu, G.A., Raoul, F.D., \& Okpachu, S.A. (2011). Evaluating the constraints \& opportunities of maize production in West region of Cameroon for sustainable development. Journal of Sustainable Development in Africa, 13(4), 189-194.

7. Kukta. F. (2011). Open-pollinated verses hybrid maize cultivars. Northern Plains Sustainable Agriculture Society Farm Breeding Club. LaMoure USA.

8. Ayeni, L.S. (2011). Integrated plant nutrition management: A panacea for sustainable crop production in Nigeria. International Journal of Soil Science, 6, 19-24.

9. Okeke, U. (2014). Economics of fresh maize production in Anambra East Local Government Area of Anambra state, Nigeria. Journal of Science and Multidisciplinary Research, 6(1), 22-33.

10. Nkamigbo, D.C., Nwoye, I.I., Makwudo, E.O., \& Gbughemobi, B.O. (2018). Economics of maize production in Oyi Local Government Area of Anambra State, Nigeria. International Journal of Agriculture and Biosciences, 7(2), 61 - 64. 
11. Oladejo, J.A., \& Adetunji, M.O. (2012). Economic analysis of maize (zea mays) production in Oyo state of Nigeria. Agricultural Science Research Journals, 2(2), 77-83.

12. Oyewo, I.O., \& Fabiyi, Y.L. (2008). Productivity of maize farmers' in Surulere Local Government Area of Oyo State, Nigeria, International Journal of Agricultural Economics \& Rural Development, 1(2), $8-15$.
13. Fawole, O.P., \& Oladele, O.I. (2007). Sustainable food crop production through multiple cropping patterns among farmers in South Western region of Nigeria. Journal of Human Ecology, 21(4), 245249.

14. Olalinde, L.O., Manyongn, V.M., \& Akintola, J.O. (2007). Attitude towards risk among maize farmers in dry savanna zone of Nigeria: Some prospective policies for improving food production. African Journal of Agricultural Research, 2(8), 399-408. 